\title{
Is India ready to incorporate Sex education in Academic curricula
}

\author{
Dr. Kumari Vineeta \\ Faculty of Education, S.M. College, T.M. Bhagalpur University, Bhagalpur, India
}

\begin{abstract}
Indian society is changing very rapidly. A fearsome scene is being created with the spread of STD/AIDS/HIV. As current data is also speaking that $20 \%$ population of the world is adolescent and out of which $88 \%$ are from developing countries. India has about 243 million adolescent and more than $50 \%$ lying in urban area. What so ever be the reason, for those STD/HIV/AIDS are becoming like a death. Religious declaration about sex discussion is a non-righteous matter or simple talk. Our future generation is gradually falling in trap of this S.T.D. Our Rajya Sabha committee on petition-2009 in his $157^{\text {th }}$ report has recommended that youth should be made a wave of marriageable age which is 21 years in case of boys whereas 18 years in case of girls and any indulgence in sex outside the institution of marriage was against the social ethics. It also recommended for evolving consensus on the implementation of sex education in school.Once it is introduced our teachersas well as educators must remain ready to get it implemented. Hence our educators must be trained properly to meet the challenge of sex education. HIV/AIDS/STD have spread like epidemic in North East of India and moving fastly in rest part also. Hence through well trained and responsible educatorsthe knowledge or training regarding values, attitudes can be impart on which successful family life and social order depends.
\end{abstract}

Keywords: Adolescence, Dubetry, Kindergarten, Spirituals, fearsome, Asceticism, erudition

\section{Introduction}

Awareness of sex is the most significant factor necessary to lead a secure life. Usual educational practices are very simple to learn, but we cannot consider sex education on the same line. It comprises of physiological, psychological and social issues, especially when we think of including it as a part of academic syllabus. As these complications occur, a question may arise in the mind of people about the need for sex education providing to the children. While children reach teenage level, lack of sex education may lead the way to their unusual behaviour. If not corrected at the exact time, it may generate problems of immature misbehaviours in these children's life.Sex is a creative energy and plays a leading part in our normal everyday life. Sex gives purpose to life and is a dynamic drive of the instinct of self-preservation. Self- preservation is based on two factors-first, eating to live and second, procreation to continue the race and is the foundation of the personality structure and behaviour problems. Satisfactory sex education includes not only the understanding of both but also the all-important ability to work out a compromise between biological wages and social restrictions.

\section{Yan maithunādi-gṛamedhi-sukhaḿ hi tucchaḿ \\ kandūyanena karayor iva duhkha-duhkham trpyanti neha krpaña bahu-duhkha-bhājah \\ kandūitivan manasijaḿ vișaheta dhìrah \\ Śrīmad Bhāgavatam 7.9.45}

Sex life is compared to the rubbing of two hands to relieve an itch. Grhamedhis, so-called grhasthas who have no spiritual knowledge, think that this itching is the greatest platform of happiness, although actually it is a source of distress. The krpanas, the fools who are just the opposite of brāhmanas, are not satisfied by repeated sensuous enjoyment. Those who are dhïra, however, who are sober and who tolerate this itching, are not subjected to the sufferings of fools and rascals

We are living in an era when healing sciences have to devote more attention to the mental health along with efforts for physical well-being. A sound sex education or emotional integration is the basis of mental health. Attention to this neglected phase of human life deserves immediate attention. But unfortunately even now talking about sex is regarded as a taboo or something very sinful. The present day attitude is a prejudice against giving any information to young people on sex life. Parents have neglected to treat the matter in a serious and straight forward manner. Teachers ignore it, text books and school courses-to which the subject should naturally belong - have carefully avoided any mention of it, or touch upon it in a most superficial and indirect manner. The physicians too have given help only when called upon to attend at a time when the disease has already advanced. Some of the important reasons for this state of affairs are:-(a) False sense of prudency on the part of the adults. (b) Ignorance of importance of sex knowledge for happiness of family life.(c) The belief that innocence and purity are achieved through ignorance of these factsand such innocence should be preserved 
as long as possible.(d) A number of orthodox educationists believe that if we were to give education of this nature we should probably start something that we would be unable to control - as we would be putting a new idea in our children's heads, which may act as a dangerous weapon.

\section{Need For Educating Mass}

Ideally instruction in sex matters begins at home when the child asks questions but unfortunately the parents are unwilling or unable for fear of being vulgar to give him the answers he needs. The parents neither tell the meaning of word 'Sex' nor they explain to them the physiology of menstruation or nocturnal emission, nor do they ever encourage them to ask questions about sex; nor are they ever given proper sources from where to find out about sex. The reason is because we have built around ourselves, through generation of tradition, an atmosphere of superiority, of awe and supreme dignity which the timidity of the child cannot penetrate. The result is that the normally curious child starts looking for information which at his tender age can only come from mates of his own age or from elsewhere. Later, "in the voyage of life when he sets forth from the carefree lagoons of childhood into the turbulent domains of adult life, assailed by under-currents of fear, shame and guilt, overshadowed time and again by clouds of misfortune and disappointment, saturated constantly in a torrential rain of tension, distracted by the ever projection rocks of psychological disaster." He is thus not piloted to safety on this his maiden and inevitable voyage. He is deserted in the foolish hope that he will go through safely.

\section{Objective Of Sex Education}

Some of the most comprehensive programmes now being operated in the Western countries cover the entire human life cycle. According to Dr.David Mace the teaching suitable adjusted to their needs, is given to the five different groups of persons:-

(a) Engaged or betrothed couples. To prepare them for the adjustments of marriage which they will soon have to make. (b) Expectant parents. To teach them what should be known about infant and child-care. (c) Parents of pre-puberty children. To help them to deal with their children's question, problems and developmental adjustments.(d) Parents of adolescents. To enable them to understand the complex problem of growth and adjustments of the teen years.(e)Young people from puberty to make selection. To guide them in understanding their sexual and emotional development, and to help them to form good behaviour patterns and sound criteria of mate select on."

Such a comprehensive programme of family education combines four streams of teaching, viz:--(a) Teaching on sex and reproduction. This concerned not only with anatomical, psychological and biological facts but also with healthy emotional attitudes and acceptable ethical standards before and after marriage.(b) Teaching on relations between men and women. This covers emotional attitudes and correct behaviour patterns, both in marriage and outside it.(c) Teaching on Parent-Craft. This covers both the physical and emotional needs of the child, the process of socialization in the family, and the establishment of good parent-child relations.

(d) Teaching on home-making. This takes in all the practical arts required in the setting up and maintenance of a good home/house planning, distribution of work, management of finance, family health and recreation and the like."

Sex education should begin in the home, not later than the time, when child asks its first question about the origin of life. It should proceed in easy progressive and development and in human relationship. Hence, sex education should be a continuous and life-long process designed to give biological, psychological and spiritual understanding in the principle of personal relationships to the peoples of the world, so that they can acquire standards of responsible behaviour in their sexual life which are devoid of fear and guilt and are in a wise relationship, not only to their religious and cultural background, but also to the needs of mankind in general.Let us see how different agencies can contribute to the teaching of sex education.

\section{Educating Within The Family And Home}

The most powerful influence in the child's life is his own family background. Children from happy homes have the best chances of succeeding in marriage. Formally and informally, by words, example and attitude, parents are the best educators in family life, be they good, bad or indifferent. In the home the parents unconsciously educate their children to the way they behave towards each other by their casual discussions of neighbour's divorces or family quarrels, by the manifestation of their own attitudes towards marriage, parenthood, morality and the individual's rights and duties. As the adolescent of today will soon marry and join the parent generation genuine preparation of the young people has to be made if they are to make their full contribution to the society as men and women, husbands and wives, the fathers and mothers of the future.

A boy or a girl who is emotionally immature, short tempered and evades responsibility is not likely to become and understanding husband or a sweet tempered wife, or a capable and successful parent, merely because he or she is married. A stable, happy family is, therefore, necessary for the emotional development of the children. Researches have revealed that few parents, without help and guidance, are equal to the task of giving sex 
education to their children. Often they are too embarrassed and self-conscious to communicate this material to their children.

\section{Educating At School And University Level}

Since parents fail to give their children adequate guidance about sex and marriage, the school must try to make up for their deficiency. The school can give more detailed and systematic teaching than the parents would be capable of, and it can ventilate this subject in a wholesome way and to eliminate the unhealthy discussions which are otherwise likely to take place among the children themselves.

Suitable curriculum should be drafted to cater for the needs of the youth both at the school and University level. In the Universities attempts should be made to provide sex education. It can be very profitably carried out as an extra-curricular activity. From the kindergarten up to Higher secondary level the scheme should be worked out and implemented without even mentioning the word 'sex', through subjects like Nature Study, General Science and Civics.

Such a programme for its effective implementation envisages the existence of skilled workers, carefully selected and suitably trained educator. In this connection the effective us of seminars, workshops, study groups, refresher courses, etc., to enable parents, teachers, doctors, nurses, priests, the health officers, social workers and educators, working with children and adolescents, to develop better understanding and sounder attitudes cannot be ignored. At the same time our regular curriculum for the training of teachers, doctors, nurses and parents needs to be geared more and more too imparting proper instruction and guidance in the field of sex, marriage and parenthood. Talks, lectures, audio-visual aids, suitably illustrated text books as well as individual guidance and counselling should form an essential part of the instruction and guidance.

\section{Social And Political Perspective Of Sex Education}

There is a debate going on currently about the advisability of providing basic sex education to school children in the Indian state of Maharashtra. The state education minister had recently announced that sex education would be made compulsory. However, this announcement is being greeted with heated opposition by other legislators in the House.A parliamentary committee headed by senior BJP leader M Venkaiah Naidu has disfavoured introduction of sex education in schools. National AIDS Control Organization (NACO) and the Ministry of Human Resource Development (MHRD), Government of India, which led to a major controversy in 2007.The ardent opponents argued for a ban on starting sex education in schools on the ground that it corrupts the youth and offends 'Indian values'. At the same time, attempt towards the introduction of sex education at school level in India met with opposition from the fundamentalists arguing that it may degrade the tender minds and destroy the rich family systems in India. Through few politicians and religious leaders have opposed the introduction of sex education in schools, studies. A recent study from Nigeria presents paramount significance of providing sexual education to youth that helped them to develop critical thinking and insights on range of family life. It helped to prevent adolescent pregnancy, abortion, HIV/AIDS and sexual abuse. A study in India revealed that majority of school teachers was in favour of imparting sex education to school children. Fourteen years of age was considered to be the most appropriate for imparting sex education by 28.6 precent of school teachers. School teachers and doctors were considered to be the most appropriate persons for providing sex education. Majority of mothers believed that discouraging pre-marital intercourse should be most important objective of sex education. A survey conducted in Hyderabad and Secunderabad cities of India found that the major sources of information on sexual matters among adolescents were books and films, followed by friends. Health survey shows that majority of men and women in India favour family life education. According to the Youth Study in India, 83 percent of young women (aged 15-24 years)felt the need to impart family life education. The study was conducted in the following selected Indian states Andhra Pradesh, Bihar, Jharkhand, Maharashtra, Rajasthan and Tamil Nadu. The attitudes and behaviour of youth are usually influenced by socioeconomic cultural and demographic characteristics.

\section{Statistical Analysis}

Based on the available stastical information I tried to establish a social and emotional relationship between the pairs of opposite sex.Our parameters were (a) Perception of youth men \& women regarding family life/sex education should be provided at age. (b) Perception of youth men \& women regarding best person to impart sex life/family life. (c) Perception of youth men \& women who received family life. To have a quick observation it Is presented through graph as noted. 
Table 1- Perception of youth men and women regarding family life/sex education should be provided at age

\begin{tabular}{|c|c|c|c|}
\hline Age(years) & $\begin{array}{c}\text { \%Men } \\
(\mathbf{X})\end{array}$ & $\begin{array}{c}\text { \%Women } \\
(\mathbf{Y})\end{array}$ & $\begin{array}{c}\text { Product moment } \\
\text { correlation }\end{array}$ \\
\hline Below 12 & 2.8 & 2.6 & \multirow{2}{*}{0.90} \\
\hline $12-14$ & 12.1 & 23.6 & \\
\hline $15-17$ & 47.5 & 42.6 & \\
\hline 18 or above & 35.4 & 25.5 & \\
\hline
\end{tabular}

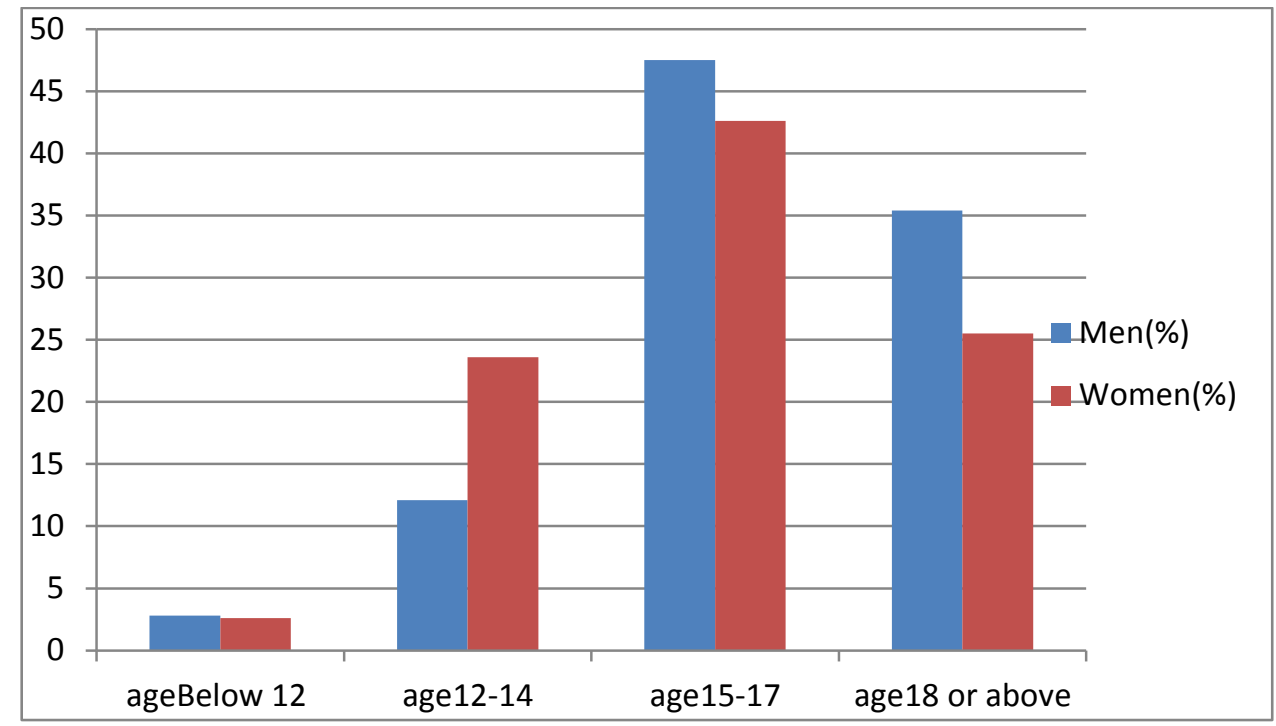

Table 2- Perception of youth men and women regarding best person to impart family life/sex

\begin{tabular}{|c|c|c|c|}
\hline Source & $\begin{array}{c}\text { \%Men } \\
(\mathbf{X})\end{array}$ & $\begin{array}{c}\text { \% Women } \\
(\mathbf{Y})\end{array}$ & $\begin{array}{c}\text { Product moment } \\
\text { correlation }\end{array}$ \\
\hline Parents & 5.9 & 33.8 & \\
\hline Siblings & 0.4 & 56 \\
\hline Spouse/partner & 0.2 & 2.4 \\
\hline Teacher & 44.8 & 27.3 \\
\hline Friend & 21.2 & 11.4 \\
\hline Health Care Provider & 23.2 & 14.4 \\
\hline Youth Club/NGO & 0.9 & 0.4 & \\
\hline
\end{tabular}

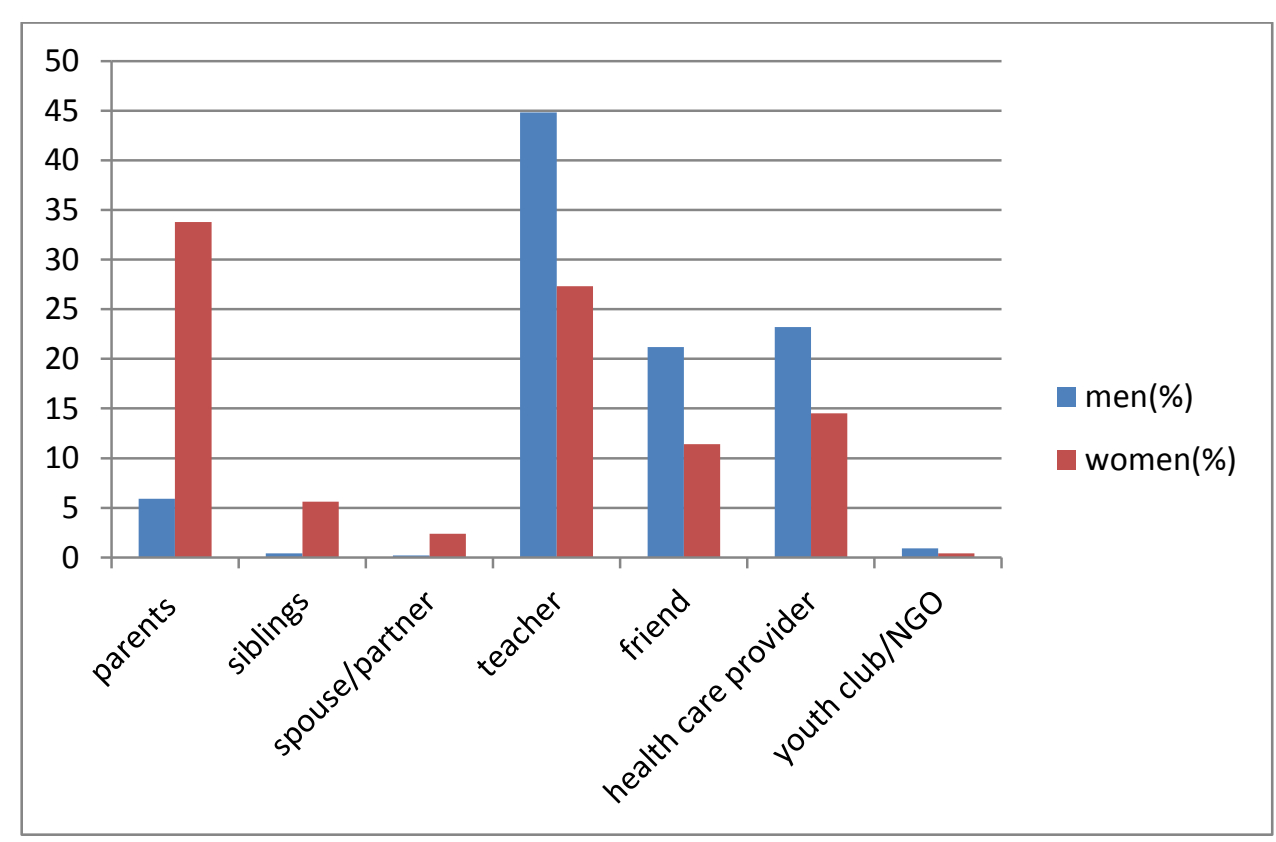


Table 3-Experiences of youth men and women who received family life/sex education

\begin{tabular}{|l|l|l|c|}
\hline Source of family/sex life & $\begin{array}{l}\text { \%Men } \\
(\mathbf{X})\end{array}$ & $\begin{array}{l}\text { \%Women } \\
(\mathbf{Y})\end{array}$ & $\begin{array}{c}\text { Product moment } \\
\text { correlation }\end{array}$ \\
\hline School/college & 80.0 & 87.9 & \multirow{2}{*}{0.99} \\
\hline Gov. prog./camp & 16.3 & 11.8 & \\
\hline NGO prog./camp & 6.4 & 5.1 & \\
\hline
\end{tabular}

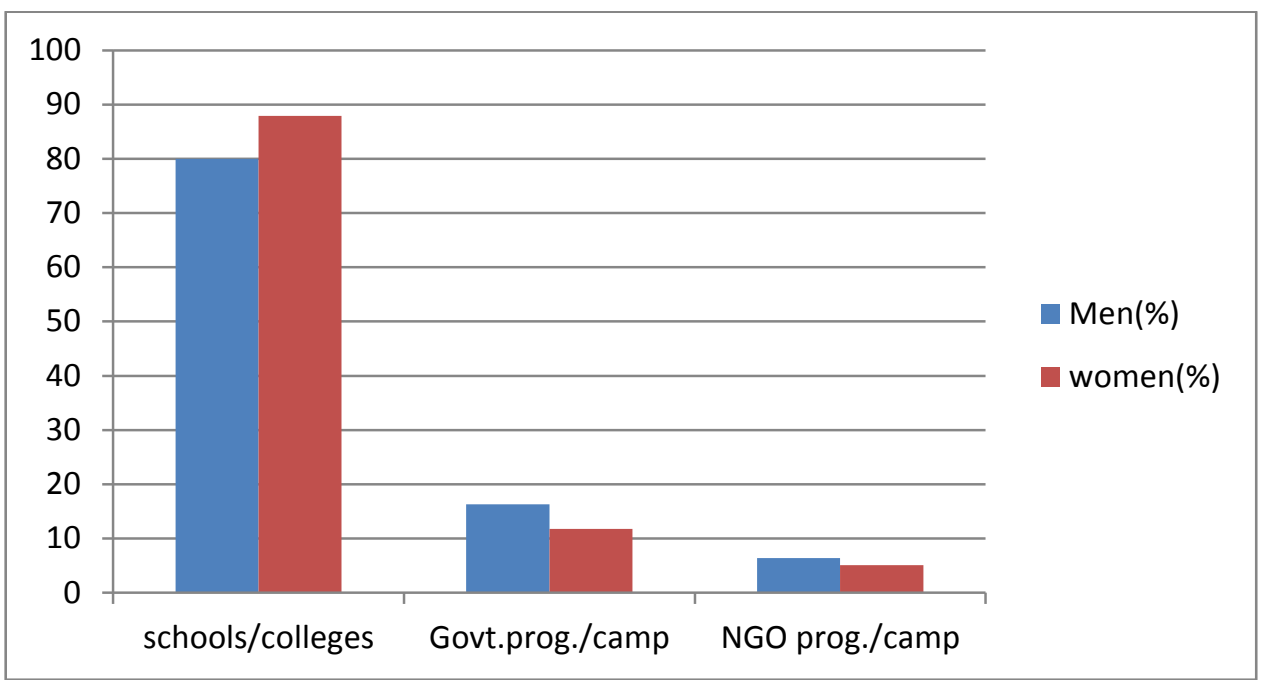

\section{Statistical result:}

There is a perfect cordial relationship to the extent of $90 \%$ and $99 \%$ in X and Y for I and III case where as when we look case II the result seen surprisingly different, here $\mathrm{X}$ and $\mathrm{Y}$ have minimum relation about $38 \%$ means $\mathrm{X}$ and $\mathrm{Y}$ have quite different views about the best person to impact sex life/family life.

\section{Conclusion}

The primary objects of sex-education or family life education are: (a) To impart correct, factual knowledge, skill, abilities and understanding regarding sex and reproduction to the child according to its age; (b) To prepare young adolescents to expect normal physical and psychological change at poverty (c) To develop in young adults a wholesome positive attitude towards sexual behaviour compatible with the demands of their society not a negative one based on fear of venereal disease, shame or divine retribution(d) To inculcate into the adult that marriage is unification, not only of bodies but of ideas and ideals and the sexual intercourse is not mere tax-free entertainment but the ultimate expression of love and devotion towards one another-with and abiding desire to contribute to each other physical and emotional needs, to help each other grow and develop and to 'care' for another;(e) To teach them to accept each other for what they are and not to try to demand something from each other which neither of them could give - and to teach other 'giving' rather than taking;(f) To install into parents the necessity of a correct child-parent. Relationship and the responsibilities of parenthood (g) To impart training for home-making and for successful participation in family life. Sex education was equally important in ancient India also as pronounced in B.Gita by Lord Krishna in 7.11 recited as:-

\section{Balam balavatam caham Kama raga vivarjitam | \\ Dharmaviruddh bhutesuKamosmi bharatarsobhal|}

Meaning here by the strong man's strength should applied to protect the weak, not for personal aggression similarly sex life according to religious principle should be for the propagation of children not otherwise. The responsibility of parents is then to make their off spring Krsna conscious

\section{Recommendation}

State and society both should be of concurrent view to adopt essential and effective sex education within school through in service perfectly trained teacher or educator on mass scale. Social media should come forward and have tobe vigil if liberalised may not be commercialised .Famous ancient scholar economist and thinker Kautilya was of the views that son be treated as friend on Adolescence that recite

\section{Lalyet panch varshani,dash varshani tadyet |}

Ref:-Chanakyaneeti-3.18

Prapttupanchamevarshe putram mitrawadacharet $\|$

Means to take son as friend after the age of sixteen. 
Recently huge number of sexual assault case are coming in to light that has shaken the basic frame work of social ethics as Raja Bhartaruhari a great King turned into sage of ancient India(King Uggaini) in his life had real working knowledge of romance, ruling, rulemaking and asceticism, has expressed his opinion regarding the nuscence of Kam dev Hindu sex God as

\section{Shringarshatakastawanmahatwanpandityamkelintwamvivekitah $\mid$ Yawajajalwantinangighuhatahpancheshupawakah \|}

Ref: -shringarshatakas by Raja Bhartaruhari soloka no.76 Meaning here by, as fire of sex once comes into the mind of a human being he loses his all erudition.

Hence it is my humble request to policy makers of India through this paper to come forward to save Adolescence of our future generation. Make sex education effective through well trained educator's right from school.

\section{Acknowledgement}

I do acknowledge with gratitude to IIPS for its stastical information and Dr. J Choudhary University professor \& former Dean Students' welfare T.M.B University for encouragement in making this paper. I also acknowledge my husband Tathagat Priyadarshi for Information Technology and Computing support and my only three years old son in maintaining himself for peace as well as my mother-in-law for her continuous support and blessing during the whole research work.

\section{References}

[1]. Aniebue P.N. “ Knowledge and attitude of secondary school teacher in Enugu to school based sex education”,Dec.2007,vol.10(4) ,304-308,NCBI,USA

[2]. Bay Laina Y.andCheng "The Trouble of Teen Sex: The construction of adolescent sexuality through school-based sexuality education", 2003, Vol. 3, No. 1, Carfex publishing, USA.

[3]. Benzaken Tami, Papel Ashutosh H. and Gill S.Pramjit, "Exposure to and opinion towards sex education among adolescent students in Mumbai: a cross sectional survey", BMC Public Health-Oct.2011.

[4]. Bhagwat Gita by Lord Krishna in 7.11

[5]. Gandhi K.M. "self-Restraint versus Self-Indulgence”, pg-8.

[6]. Garur Puran

[7]. Grant L.M. and Demetrious E. “Adolescent sexuality”, Dec.1988, 35(6):1271-89, NCBI,USA.

[8]. http://www.indianmba.com/Faculty_Column/FC957/fc957.html-Das Smitha "Sex education in India -Need of Hour"

[9]. Padam Puran

[10]. Pueschel S.M. and Scola P.S. "Parents perception of social and sexual function in adolescent with down's syndrome", June 1988, 32(3), 215-20, Journal of Intellectual Disability Research, USA.

[11]. R-Veda.

[12]. "Sex education in India -need of the hour" an essay by CSEINDIA PORTAL, March6, 2003, cited on Apr.5, 2014.

[13]. Shringar Shatakas by Raja Bhartaruhari shloka no. 76.

[14]. Śrīmad Bhāgavatam 7.9.45

[15]. Tripathi N. and Sekher T.V. "Youth of India ready for sex education? Emerging evidence from national survey" Aug 9, 2013; PLOS One; 8(8):e71584.

[16]. Tripathi V. "Do we need sex-education in schools" Article in India Insight, Apr.30, 2009. 